\title{
INTERNATIONAL LEGAL PROTECTION FOR CLIMATE REFUGEES: WHERE LIES THE HAVEN FOR THE MALDIVIAN PEOPLE?
}

\author{
Simran Dolla*
}

\begin{abstract}
Climate change and sea level rise are not just mere words for the Maldivian people; they are a grim reality that is consuming their nation. Sea level rise presents one of the gravest dangers for the Maldives because of its already low-lying characteristics. As the levels continue to rise, the nation is sinking into extinction. Some 300,000 people of the Maldives are on the brink of losing their homes and becoming climate change refugees. The existing international laws are not only ill-equipped to provide protections or the much-needed relief, they also make no mention of climate change refugees. Therefore, as the Maldivians await the result of the 2015 Paris Convention whose purpose is to achieve a binding universal agreement on climate change, they continue to face numerous human rights violations. Additionally, the loss of a nation does not only mean the loss of a home, it also means the loss of sovereignty at the international level. However, at the present time, finding a safe haven for its people is at the top of the Maldives agenda. The former president of the Maldives, Mohamed Nasheed, fought vigorously to bring the issue of sea level rise and climate change to the forefront. Knowing that such a day where he would have to move his people was not far in the distance, he also made plans to relocate. India and Australia have both been considered possible new homes; however, are both countries willing to take in such a large infiltration of refugees? What are the repercussions of moving to these countries? Would an artificial island possibly be the home the Maldivians are looking for? This article examines the options the Maldives has for relocation and why perhaps an artificial island may be a better solution.
\end{abstract}

Keywords: Maldives, climate change, refugees, justice, protection, international law.

doi: http://dx.doi.org/10.4314/jsdlp.v6i1.1

* J.D. (cum lande), Florida A\&M College of Law, United States of America. 


\section{INTRODUCTION}

beautiful chain of over 1,1900 islands that lie in the Indian Ocean
just south of India, the Maldives is considered a paradise for many. With its luxurious hotels and breath-taking resorts, it has been a popular destination for the rich and famous. However, the very reason that makes the Maldives thrive is becoming the sole reason for its annihilation. As the climate continues to change, thereby causing the sea levels to rise, the gorgeous white sands the Maldives is famous for will soon cease to exist. The entire nation will be submerged. Some 300,000 people of the Maldives are on the brink of becoming homeless.

When the now-ousted President Mohamed Nasheed took office in the Maldives in 2008, he did not expect climate change to be a focus of his presidency. After multiple jail terms, eighteen months of which were spent in solitary confinement, and two and a half years in exile, Mohamed Nasheed was finally able to win the election as the fourth president of the Maldives in 2008. ${ }^{1}$ As soon as he took over the presidency, he was faced with the daunting task of keeping the Maldives afloat in the Indian Ocean. Putting everything else aside, Nasheed focused on what he believed was their "most important fight" - the fight for their survival. ${ }^{2}$

Nasheed put the climate change discourse on the map and brought the problems it would cause to the attention of the international community by holding the first underwater cabinet meeting in which he signed a document calling for global cuts in carbon emissions. ${ }^{3} \mathrm{He}$ advocated heavily for small island states during the Copenhagen Summit in 2009, the result of which was promising as world leaders from nations, including China, pledged to cut emissions. ${ }^{4}$ However, Nasheed was forced to step down from his position as president in 2012 and along with climate

\footnotetext{
The Island President (Samuel Goldwyn Films 2011).

ibid.

ibid.

4 Fifteenth Session of the Conference of the Parties to the United Nations Framework Convention on Climate Change and Fifth Session of the Meeting of the Parties to the Kyoto Protocol, Centre for Climate and Energy Solutions, December 7-18, 2009 <www.c2es.org/international/negotiations/cop-15/ summary> accessed 18 February 2015.
} 
change, his recent arrest and conviction has brought on other uncertainties for the Maldives. ${ }^{5}$

Section 2 of this article describes the causes of sea level rise and provides a brief background on the archipelago known as the Maldives, and the effect the rising sea will have on this vulnerable island nation. Section 3 examines the existing legal protections available to the Maldivian people once they become climate change refugees. It discusses the Refugee Convention, the United Nations Framework Convention on Climate Change (UNFCCC), the Kyoto Protocol, and the human rights violations the Maldivians will suffer because climate change refugees have no protections under these international documents. Section 3 also briefly discusses the text of the upcoming UNFCCC Conference of the Parties to be held in Paris, France in November 2015 and its importance to small island nations.

Section 4 evaluates possible proposals for the Maldives. It addresses the Montevideo Convention and how the Maldives can retain its sovereignty if it chooses to relocate, which is one of the options the Maldives is actively considering, and considers the responsibilities of the host and home states upon relocation. Section 4 also proposes an artificial island as the best option for the Maldives and the possible steps it will need to take as an artificial island to gain recognition as a state. Section 4 discusses the option for the Maldives to migrate to Australia or India and the opportunities and challenges it can anticipate if it decides to relocate to either country. Section 5 concludes the paper.

\section{CLIMATE CHANGE AND IMPACT ON THE MALDIVES}

\subsection{Climate Change and Sea Level Rise}

As the radiation from the sun is the primary source of energy for the

5 Mohamed Nasheed was ousted as President of the Maldives in 2012 and in March 2014 , he was found guilty of terrorism and sentenced to 13 years in prison. Hailed as the "Mandela of the Maldives," and considered the hero of the climate change movement, his sentence is likely to exacerbate the instability of the island. See "Former Maldives president Mohamed Nasheed jailed for 13 years." The Guardian <www.theguardian.com/world/2015/mar/14/former-maldivespresident-mohamed-nasheed-jailed-for-13-years> accessed 14 March 2015. 
earth, a balance exists between incoming and outgoing solar radiation. ${ }^{6}$ However, minor imbalances can cause global heating or cooling. ${ }^{7}$ Natural sources of forcing, a term used to describe interruptions in the main elements that influence the earth's climate, "are behind geological shifts in climate from extreme glacial periods of extensive ice coverage to interglacial periods of ice retreat."

Rising levels of greenhouse gases, primarily carbon dioxide in the atmosphere, have warmed the earth and are the driving force behind the changes in the earth's climate. ${ }^{9}$ Carbon dioxide concentrations amount to about 80 per cent of the total caused by greenhouse gases. ${ }^{10}$ Carbon dioxide emissions are a major factor in mean global surface warming so much so that even if the current emissions were stopped, the effects of the emissions would still be felt for many centuries to come. ${ }^{11}$ Rising levels of carbon dioxide are bringing about a wide range of impacts, such as sea level rise; melting of snow and ice; more extreme heat events; more extreme storms, fires and droughts; and severe rainfall and floods. ${ }^{12}$

Scientists believe that sea level rise will be the single most overwhelming geological change in history. ${ }^{13}$ Sea level rise will transform the shape of the earth in a way humans have never imagined. Continents will be reshaped and while some will lose part of their states, others will lose their entire sovereign territory. Change in sea level can occur for several reasons, but primarily it is an element of the ocean temperature and the temperature of the atmosphere. ${ }^{14}$ As levels of carbon dioxide increase in the air and warms the atmosphere, which will in turn warm the ocean, this will cause the ice sheets to melt into the ocean. ${ }^{15}$

6 Randall S. Abate \& Dr Sarah Ellen Krejci, 'Climate Change Impacts on Ocean and Coastal Law: Scientific Realities and Legal Responses’, in Randall S. Abate (eds.), Climate Change Impacts on Ocean and Coastal Law: U.S. And International Perspectives 1, 3 (2015).

7 ibid.

8 ibid.

9 ibid.

10 ibid.

11 ibid 5.

12 'What is climate change?' Department of Ecology State of Washington, <www.ecy.wa.gov/climatechange/whatis.htm> accessed 13 January 2015.

13 John Englander, High Tide on Main Street: Rising Sea Level and the Coming Coastal Crisis (2012) 3.

14 ibid 7.

15 ibid 71. 
In the past, polar ice melt was the major cause of sea-level rise, ${ }^{16}$ but today, along with the natural processes, sea level rise has been significantly exacerbated because of human activity such as emissions from cars. ${ }^{17}$ Though it was confirmed by the Fourth Assessment Report of the Intergovernmental Panel on Climate Change (IPCC) in 2007 that humans are a key factor in the hastening of climate change, ${ }^{18}$ the Fifth Assessment Report released in 2013 has concluded that humans are actually the primary factor in the hastening of climate change. ${ }^{19}$ Gasoline, methane and propane are fossil fuels that contain mostly carbon; and when these fuels are burned, carbon dioxide is formed because of their reaction with oxygen. ${ }^{20}$ Additionally, the industrial revolution has led to the destruction of forests, which has further contributed to the increase in carbon dioxide. ${ }^{21}$ Sea levels rose about 15-20 centimetres (roughly 1.5 to $2.0 \mathrm{~mm}$ / year) during the 20th century, and is expected to continue rising significantly. ${ }^{22}$ Pursuant to the satellite measurements taken over the past ten years, the rise in sea level has increased to about $3.1 \mathrm{~mm} / \mathrm{year},{ }^{23}$ which means that in the past 100 years, the sea level has increased roughly by 6.5 inches. $^{24}$

The growth and demise of the glaciers and ice sheets significantly affect sea level because that is what changes the volume of the water. ${ }^{25} \mathrm{As}$ the glaciers and ice caps melt, the water in the ocean rises, thereby increasing the level of the sea. ${ }^{26}$ If the ice in Greenland were to melt, the

16 Abate \& Krejci (n 6) 5.

17 'Oceans and Sea Level Rise Consequences of Climate Change on the Oceans', Climate Institute, $<w w w . c l i m a t e . o r g / t o p i c s / s e a-l e v e l />$ accessed 6 February 2015.

18 Vikram Kolmannskog, 'Climate Changed: People Displaced', in Scott Leckie, Ezekiel Simperingham \& Jordan Bakker (eds.), Climate Change and Displacement Reader 36 (2012).

19 Abate \& Krejci (n 6) 2.

20 'How does carbon dioxide cause global warming?' Science Theatre at Michigan State University (Aug. 31, 1994), <www.pa.msu.edu/sciencet/ask_st/ 083194.html> accessed 10 February 2015.

21 ibid.

22 'Oceans and Sea Level Rise Consequences of Climate Change on the Oceans' (n 17).

23 ibid.

24 'GlobalView: Climate Change in Perspective' Bloomberg view $<$ www.bloombergview.com/interactives/climate-change-in-perspective/ \#slide $=8>$ accessed 24 February 2015.

25 Orrin H. Pilkey \& Rob Young, The Rising Sea (2009) 34.

26 ibid. 
sea level would increase by about five to seven metres. ${ }^{27}$ Such a considerable sea level rise would be detrimental to many coastal areas in the world and would lead to the disappearance of many states.

\subsection{The Vulnerability of the Maldives to Sea Level Rise}

The Maldives is an Indian Ocean archipelago with about 1,190 islands covering an area of more than $90,000 \mathrm{~km}$ and stretching $820 \mathrm{~km}$ in length. ${ }^{28}$ With a population of fewer than 350,000 people, 80 per cent of the islands are less than 1.5 meters above sea level, making it one of the most lowlying countries in the world..$^{29}$ The Maldives is the smallest Asian country in both population and land area. ${ }^{30} \mathrm{It}$ is also the lowest country on the planet and also the country with the lowest highest point in the world, at 2.3 meters $\left(7 \mathrm{ft} 7 \mathrm{in}\right.$ ). ${ }^{31}$ As the flattest country on the earth, the Maldives islands are made up of live coral reefs and sand bars, situated on the top of a submarine ridge, which is 960 kilometres long and runs from north to south in the Indian Ocean. ${ }^{32}$

The history of the Maldives islands dates back 3000 years to when mariners came from different parts of the world and settled there. ${ }^{33}$ However, only 200 of the almost 1,190 islands are inhabited with the majority of the population living in the country's capital, Malé. ${ }^{34}$ After tourism, fishing and fish processing are the second largest industry in the Maldives, but rising sea levels have caused significant changes in the marine environment. ${ }^{35}$ Rising sea levels and climate changes have not only affected the economy of the Maldives, it has also put the people at a high risk of extinction.

27 ibid.

28 Raquel Rolnik, 'Mission to Maldives Report of the Special Rapporteur on the Right to Adequate Housing', in Scott Leckie, Ezekiel Simperingham \& Jordan Bakker (eds.) Climate Change and Displacement Reader (2012) 247.

29 'Maldives', SAARC Coastal Zone Management Centre <www.sczmc.org/281/ maldives/> accessed 7 March 2015.

30 ibid.

31 ibid.

32 'Republic of Maldives' Climate hot map <www.climatehotmap.org/globalwarming-locations/republic-of-maldives.html> accessed 7 March 2015.

33 'Maldives History People have lived in these islands for over 3000 years' MalDives <www.mal-dives.com/maldives/info/maldives_history.html> accessed 8 March 2015.

34 Helen Chapin Metz, Indian Ocean Five Island Countries (1994) 264.

35 Justin Hoffmann, 'The Maldives and Rising Sea Levels' Ice Case Studies (May 2007) <www1.american.edu/ted/ice/maldives.htm> 
On 26 December 2004, an earthquake with a magnitude higher than 9.0 occurred off the shore of Sumatra Indonesia, ${ }^{36}$ generating large tsunamis, which caused extensive damage to coastal communities in countries along the Indian Ocean. ${ }^{37}$ The tsunami reached the Maldives three hours after the tremors were felt. ${ }^{38}$ Of the 199 inhabited islands, 69 were damaged (out of a total of approximately 1,190) 20 were largely devastated, and 14 had to be evacuated..$^{39}$ Approximately 100,000 people were severely affected, with 82 being killed and about 12,000 became displaced while 8,500 were put in temporary shelters. ${ }^{40}$ However, the tsunami was a mere glancing blow compared to the direct hit that the nation faces now from sea level rise.

In July 2007, former President Gayoom of the Maldives delivered a speech to the Royal Commonwealth Society in London stating that despite twenty years of international advocacy on the matter, the climate change problem is worse today than it has ever been. ${ }^{41}$ In November 2007, the Maldives hosted a Small Island States Conference on the Human Dimension of Global Climate Change. ${ }^{42}$ The result of the Conference was the formation of the Male' Declaration on the Human Dimension of Global Climate Change. ${ }^{43}$ The Declaration emphasized that "small islands, low-lying coastal, and atoll states are particularly vulnerable to even small changes to the global climate and are already adversely affected by alterations in ecosystems, changes in precipitation, rising sea levels and increased incidence of natural disasters." ${ }^{44}$

36 Hermann M. Fritz, Costas E. Synolakis, Brian G. McAdoo and Riccardo Caputo, 'Maldives field survey of the 2004 Indian Ocean Tsunami' (2006) $1<$ http:// faculty.vassar.edu/brmcadoo/EERI_Maldives_FzSyMcCa3.pdf> 37 ibid.

38 'The Maldives' United National Environment Programme, (2005) $<$ www.unep.org/tsunami/reports/Tsunami_Maldives_Layout.pdf $>$ accessed 5 March 2015.

39 ibid.

40 Bruce Richmond and Helen Gibbons, 'Assessing Tsunami Impacts in the Republic of Maldives' USGS Science for a Changing World (April 2005) <http:// soundwaves.usgs.gov/2005/04/fieldwork3.html> accessed 5 March 2015.

41 Mark Limon, 'Human Rights and Climate Change: Constructing a Case for Political Action' (2009) 33 Harvard Environmental Law Review 439, 441 available at <www.law.harvard.edu/students/orgs/elr/vol33_2/Limon.pdf> accessed 5 March 2015.

42 ibid 442.

43 ibid.

44 'Maleì Declaration on the Human Dimension of Global Climate Change' (November 14, 2007) 1, available at <www.ciel.org/Publications/ Male_Declaration_Nov07.pdf> accessed 23 February 2015. 
Two years later, on 17 October 2009, a new president, Mohamed Nasheed, made a declaration demanding global carbon emissions reductions. ${ }^{45}$ The declaration was issued after a meeting was held with his officials; however, this meeting was no ordinary one. ${ }^{46}$ It took place thirteen feet underwater with the president and his cabinet wearing scuba gear. ${ }^{47}$ Nasheed became an activist for climate change reform not only for the Maldives, but also for all Small Island States (SIDS). In 2007, the IPCC concluded that even a mere one-meter increase in sea level rise in the near future would cause the Maldives to vanish from the face of the earth. ${ }^{48}$

The Maldives has an extremely high population density with significantly high levels of poverty. ${ }^{49}$ It is highly susceptible to global influences because it is physically isolated from the world markets. ${ }^{50}$ The Maldives also face daunting challenges from warming waters and sealevel rise. Permanent flooding, extreme weather forecasts, changes to the island and marine ecosystems caused by the increase in sea and surface temperatures are just a few problems awaiting the Maldives. ${ }^{51}$ The rise in sea temperature will cause damage to coral reefs and other aquatic life as well as destruction of rainwater storage tanks and sanitation systems. ${ }^{52}$ Further rise in surface temperatures causes an increased incidence of diseases such as scrub typhus, diarrheal diseases, and other mosquitoborne illnesses. ${ }^{53}$

45 Michael Gagain, 'Climate Change, Sea Level Rise, and Artificial Islands: Saving the Maldives' Statehood and Maritime Claims Through the Constitution of the Oceans' (2012) 23 Colorado Journal of International Environmental Law E Policy 77, 79 available at <www.colorado.edu/law/sites/default/files/GAGAIN\% 20_correctedv2.pdf $>$ accessed 6 March 2015.

46 ibid.

47 ibid.

48 ibid 85.

49 Maldives-Government, 'Maldives Climate Change Policy Framework' (2014) available at <www.environment.gov.mv/v1/wpcontent/blogs.dir/1/files/ downloads/Maldives_Climate_Change_Policy_Framework_draft_3.pdf $>$

50 ibid.

51 Sumudu Atapattu, 'Climate Change: Disappearing States, Migration, and Challenges for International Law' (2014) 4 Washington Journal of Environmental Law E Policy 9 available at <https://digital.lib.washington.edu/dspace-law/ bitstream/handle/1773.1/1356/4WJELP1.pdf?sequence=3>

52 ibid.

53 M Orellana \& A Johl, 'Climate Change and Human Rights: A Primer' (Revised July 2013) available at <www.ciel.org/Publications/CC_HRE_23May11.pdf> accessed 13 February 2015. 
Notably, the most crucial of all challenges is the displacement of people as well as the formation and spread of disease. ${ }^{54}$ Scientists fear that the Maldives will be underwater by 2050 or $2100 .{ }^{55}$ The submersion of the Maldives will cause more than 300,000 to become homeless and will prompt a series of new problems for these displaced nationals. For the first time during the Small Island States Conference on the Human Dimension of Global Climate Change, a coalition of Small IslanD States (SIDS) posed a question regarding how climate change affects the human rights of citizens. ${ }^{56}$ The question was answered in the Male' Declaration that "climate change has clear and immediate implications for the full enjoyment of human rights." 57 Therefore, along with the fact the Maldivians would no longer have a home, they would also be facing several human rights violations.

\section{LEGAL FRAMEWORK FOR CLIMATE REFUGEES}

The first issue to consider in addressing the legal framework for refugees is that there is no existing law that protects climate change refugees. The Convention Relating to the Status of Refugees makes no mention of climate change or environmental refugees and other potentially relevant but non-binding human rights instruments also do not address climate change refugees. Moreover, even the existing legal framework on climate change offers no real protections to climate change refugees. All hopes for the small-island developing states now rest on the Paris Convention of 2015 , the text of which focuses primarily on funding and lowering greenhouse gas emissions.

\subsection{Status of Refugees and Human Rights of Refugees}

\subsubsection{Convention Relating to the Status of Refugees}

The 1951 UN Convention Relating to the Status of Refugees uses the term "refugee" to apply to those individuals who fled their home country:

54 ibid.

55 About the Maldives, The Island President <http://theislandpresident.com/aboutthe-maldives/> accessed 10 March 2015.

56 Limon (n 41).

57 'Maleì Declaration on the Human Dimension of Global Climate Change' (n 44) 2. 
as a result of events occurring before 1 January 1951 and owing to well-founded fear of being persecuted for reasons of race, religion, nationality, membership of a particular social group or political opinion, is outside the country of his nationality and is unable or, owing to such fear, is unwilling to avail himself of the protection of that country; or who, not having a nationality and being outside the country of his former habitual residence as a result of such events, is unable or, owing to such fear, is unwilling to return to it. $^{58}$

Due to the fact that the Convention was written in the wake of Second World War, the definition of a refugee concentrates on persons who are not in their country of origin and are refugees as a result of events occurring in Europe or elsewhere before 1 January 1951. ${ }^{59}$ The 1967 Protocol removed the first phrase, and expanded the Refugee Convention's protection to include those that meet the qualifications of the remainder of the elements of the definition. ${ }^{60}$

As the Convention makes no mention of climate or environmental refugees, some small island states came together in 2006, formed the Male Declaration and proposed that the Convention be amended to include a new category of environmental refugees. ${ }^{61}$ The proposal has been on the table for over eight years. Unfortunately, the 2014 UN conference on Small Island Developing States once again bypassed the sensitive issue. ${ }^{62}$ The UN High Commissioner for Refugees (UNHCR) was apprehensive that the inclusion of environmental or climate refugees could potentially

58 Convention Relating to the Status of Refugees, opened for signature 28 July 1951, 189 UNTS 150 and Protocol Relating to the Status of Refugees art. 1, opened for signature 31 January 1967, 19 U.S.T. 6223, 606 UNTS 267.

59 "Refugee Protection: A Guide to International Refugee Law", UN Office of The High Commissioner, available at <www.unhcr.org/3d4aba564.html>, accessed 10 March 2015.

60 Bonnie Dochertya \& Tyler Giannini, 'Confronting a Rising Tide a Proposal for a Convention on Climate Change Refugees’ (2009) 33 Harvard Environmental Law Review 349, 362 available at <www.law.harvard.edu/students/orgs/elr/ vol33_2/Docherty\%20Giannini.pdf>, accessed 10 March 2015.

61 Elke Weesjes, 'SIDS Conference will not address issues of environmental refugees' Drop.Sun.AC.Za (29 August 2014) <http://drop.sun.ac.za/2014/09/04/sidsconference-will-not-address-issues-of-environmental-refugees/>, accessed 10 March 2015.

62 Thalif Deen, 'U.N. Conference Set to Bypass Climate Change Refugees' IPS News 25 August $2014<$ http://www.ipsnews.net/2014/08/u-n-conference-set-tobypass-climate-change-refugees/>, accessed 10 March 2015. 
demoralize the clarity of current standards. ${ }^{63}$ The UNHCR further believes that extending the current UN refugee regime will put pressure on the UNHCR to reduce the burden of refugees. ${ }^{64}$

As there is no legal instrument that specifically mentions environmental refugees, there is no protection under existing law for those individuals that have left their countries or will leave their countries in the future due to environmental threats. ${ }^{65}$ For those reasons, it is necessary to turn to scholarly literature, in which there is a vigorous hypothetical debate as to what constitutes "environmental refugee." ${ }^{66}$ In 1985, Essam El-Hinnawi of the United Nations Environment Programme drafted the first widely used definition of environmental refugee. ${ }^{67} \mathrm{He}$ describes this class of refugee as:

[T] hose people who have been forced to leave their traditional habitat, temporarily or permanently, because of a marked environmental disruption (natural and/or triggered by people) that jeopardized their existence and/or seriously affected the quality of their life. By "environmental disruption" in this definition is meant any physical, chemical and/or biological changes in the ecosystem (or the resource base) that render it, temporarily or permanently, unsuitable to support human life. ${ }^{68}$

El-Hinnawi's definition is considered to be quite broad; therefore, other authors have scrutinized and borrowed from him to create their own definitions. ${ }^{69}$ Some scholars disagree with the name and definition of "environmental refugee" altogether and propose a new name and definition as "climate change refugee." Frank Biermann and Ingrid Boas have proposed the following definition of climate change refugee: "people who have to leave their habitats, immediately or in the near future, because

63 Jeremy Kelley, 'Climate Change and Small Island States: Adrift in a Raising Sea of Legal Uncertainty’ 11 Sustainable Development Law \& Policy 56, 56 (2011) available at <http://digitalcommons.wcl.american.edu/cgi/viewcontent.cgi? article $=1474 \&$ context $=$ sdlp $>$, accessed 10 March 2015.

64 ibid.

65 Dochertya \& Giannini, (n 60) 358.

66 ibid. 363.

67 ibid.

68 ibid. See also Aurelie Lopez, 'The Protection of Environmentally Displaced Persons in International Law' in Scott Leckie, Ezekiel Simperingham \& Jordan Bakker (eds.) Climate Change and Displacement Reader (2012) 174,182.

69 ibid. 
of sudden or gradual alterations in their natural environment related to at least one of three impacts of climate change: sea-level rise, extreme weather events, and drought and water scarcity." definition has been picked at and many proposals containing new definitions have followed.

Even though a vast number of scholars have proposed new definitions, the UN has not adopted any of them. As of this writing, whether a person has been forced to leave their home due to an environmental or climate change reason, the UN will not afford them protections. This gap in legal protections poses a grave predicament for the Maldivians who are destined to become climate change refugees this century, but will not have the adequate protections afforded to them under the UN status of refugees.

\subsubsection{Other Human Rights Protections}

International human rights law requires " $[\mathrm{g}]$ overnments to act in certain ways or to refrain from certain acts, in order to promote and protect human rights and fundamental freedoms of individuals or groups." ${ }^{\prime 1}$ Adopted in 1948, the first non-binding international legal instrument on human rights, the Universal Declaration of Human Rights (UDHR), referenced basic civil, political, economic, social and cultural rights. ${ }^{72}$ Building on that nonbinding treaty, two binding human rights treaties were formed in 1966: the International Covenant on Civil and Political Rights (ICCPR $)^{73}$ and the International Covenant on Economic, Social and Cultural Rights (ICESCR). ${ }^{74}$

The ICCPR guarantees several basic rights such as the right to life, which is listed as an "inherent" right, and the right to self-determination, which allows the people to "freely determine their political status and freely pursue their economic, social and cultural development." ${ }^{\text {" T5 }}$ The

70 ibid.

71 "What are human rights?" UN Office of the High Commissioner for Human Rights, <www.ohchr.org/EN/Issues/Pages/WhatareHumanRights.aspx> accessed 4 February 2015.

72 Megan M. Herzog, “Coastal Climate Change Adaptation and International Human Rights" in Randall S. Abate (ed.) Climate Change Impacts on Ocean and Coastal Law: U.S. and International Perspectives (2015) 593, 601.

73 International Covenant on Civil and Political Rights, 16 December 1966, 999 UNTS 171, 6 I.L.M. 368 [ICCPR].

74 International Covenant on Economic, Social and Cultural Rights, 16 December 1966, 993 UNTS 3, 6. I.L.M. 360 [ICESCR].

75 ICCPR (N 73) ARTS. 1, 6. 
ICESCR protects a variety of socioeconomic and cultural rights including right to work, right to adequate housing, right to food, and right to health, to name a few. ${ }^{76}$ Further, the ICESCR requires each party "to take steps, individually and through international assistance and co-operation...to the maximum of its available resources, with a view to achieving progressively the full realization of the rights recognized in the present Covenant by all appropriate means." 77 Therefore, the treaty contemplates that though developing countries may not be able to secure all the socioeconomic rights, they must nonetheless show that they are taking the necessary steps to protect the enumerated rights. ${ }^{78}$

With the onset of severe climate change impacts, most if not all of these human rights of individuals who may become climate change refugees, such as the Maldivians, will be violated. Climate change will aggravate and intensify the weather-related disasters, which in many small island states including the Maldives, has already had a devastating effect on people and their enjoyment of the right to life. The increased flooding due to sea-level rise has taken away many Maldivians' right to adequate housing and clean water. The flooding also increases the risk of disease, which impacts the right to health and impairs the right to life.

Another major human rights concern for the Maldives, which also impinges on the right to adequate housing and enjoyment of life is whether the Maldives will lose their sovereignty as a state. The Maldives faces extinction from loss of its territory by 2050 as the sea levels continue to rise. Therefore, a question arises as to whether the Maldives will lose its sovereignty once the nation ceases to exist. Under the Montevideo Convention on the Rights and Duties of States, ${ }^{79}$ the four characteristics in the definition of a state are: (1) population; (2) a defined territory; (3) a government; and (4) a capacity to enter into relations with other states. ${ }^{80}$ However, as will be further discussed in Part III, the Montevideo Convention should permit the Maldives to remain a state despite the fact that it faces losing all its physical territory.

The UN Office of the High Commissioner of Human Rights (OHCHR) has recognized that "climate change interferes with the

76 ICESCR (n 74) arts. 6, 11, 12.

77 ibid art. 2(1).

78 Herzog (n 72) 602.

79 Montevideo Convention on the Rights and Duties of States 1933, 165 INTS 19.

80 ibid. art. 1 . 
enjoyment of human rights recognized and protected by international law." ${ }^{81}$ However, the process to prevent further violations has been slow. The ICCPR and ICESCR address a variety of human rights, yet they do not speak to climate change refugees. The Malé Declaration of 2007 had called on the United Nations Framework Convention on Climate Change (UNFCCC), the Human Rights Council, and the OHCHR for increased cooperation. Although a few resolutions acknowledging the connection between climate change and human rights have been adopted, the overall effect has been minimal. ${ }^{82}$ As discussed further below, the UNFCCC agenda has not been significantly influenced and climate change refugees remain without any considerable protections.

\subsection{International Law on Climate Change}

\subsubsection{United Nations Framework Convention on Climate Change}

In 1972, the first World Climate Conference took place, but the UNFCCC, an international treaty, was not formed and adopted until 1992 when countries joined to "cooperatively consider what they could do to limit average global temperature increases and the resulting climate change, and to cope with whatever impacts were, by then, inevitable." 83 The UNFCCC has almost a universal membership with 195 parties to the Convention. ${ }^{84}$ The ultimate aim of the UNFCCC is to avert "dangerous" human interference with the climate system. ${ }^{85}$

The UNFCCC is the main body for small-island developing states to approach for assistance when it comes to climate change; however, most if not all of the small island states believe that the UNFCCC does not provide the relief they seek. For instance, the UNFCCC does not

81 "Climate change is a global threat to human rights, UN experts warn States involved in climate negotiations" UN Office of the High Commissioner for Human Rights available at <www.ohchr.org/EN/NewsEvents/Pages/ DisplayNews.aspx? NewsID=1 5181\&LangID=E > accessed 2 March 2015.

82 Herzog (n 72) 606.

83 'Background on the UNFCCC: The international response to climate change' UN Framework Convention on Climate Change <http://unfccc.int/ essential_background/items/6031.php> accessed 4 March 2015.

84 'First steps to a safer future: Introducing The United Nations Framework Convention on Climate Change' UN Framework Convention on Climate Change $<$ http://unfccc.int/essential_background/convention/items/6036.php> accessed 4 March 2015.

85 ibid. 
address the issue of displacement in the matter of climate change. ${ }^{86}$ Some scholars argue that even though the UNFCCC does directly apply to climate change, it does have certain limitations. Docherty and Giannini state that as an environmental treaty, the UNFCCC

primarily concerns state to state relations; it does not discuss duties that states have to individuals or communities, such as those laid out in human rights or refugee law. It is also preventive in nature and less focused on the remedial actions that are needed in a refugee context. Finally, although the UNFCCC has an initiative to help states with adaptation to climate change, that program does not specifically deal with the situation of climate change refugees. Like the refugee regime, the UNFCCC was not designed for, and to date has not adequately dealt with, the problem of climate change refugees. ${ }^{87}$

The small island developing states recognize that the UNFCCC does not provide a sufficient framework or text that addresses their concerns, which is why these states have formed the Alliance of Small Island States (AOSIS). AOSIS works as an ad hoc lobby and negotiating voice for small-island developing states within the UN..$^{88}$ It is a league of small island countries that "share similar development challenges and concerns about the environment, especially their vulnerability to the adverse effects of global climate change." ${ }^{89}$ The AOSIS currently has 44 members ${ }^{90}$ who realize that significant work remains before they can witness a change being implemented.

\subsubsection{Kyoto Protocol}

The Kyoto Protocol is another international treaty that is linked to the UNFCCC. Adopted in December 1997 and entered into force in February

86 David Hodgkinson \& Lucy Young, “In the Face of Looming Catastrophe”: A Convention for Climate Change Displaced Persons, in Michael B. Gerrard \& Gregory E. Wannier (eds.) Threatened Island Nations: legal implications of rising seas and a changing climate (2013) 299, 305 available at $<$ www.ccdpconvention.com/documents/A\%20Convention \% 20 for $\% 20$ Climate\%20Change\%20Displaced\%20Persons\%20(January\%202012).pdf> accessed 17 March, 2015.

87 ibid 305-306.

88 “Alliance of Small Island States: About AOSIS" Aosis <http://aosis.org/about/ > accessed 17 March, 2015.

89 ibid.

90 ibid. 
2005, it placed an obligation on its Parties by setting internationally binding emission reduction targets. ${ }^{91}$ The Kyoto Protocol only binds the developed countries "because it recognizes that they are largely responsible for the current high levels of GHG emissions in the atmosphere, which are the result of more than 150 years of industrial activity. ${ }^{92}$ Therefore, under the common but differentiated responsibility principle that drives the Protocol, a heavier burden is placed on developed nations. ${ }^{93}$

Unfortunately, the original Kyoto Protocol expired in early December 2012. However, on 21 December, 2012, the Secretary-General of the United Nations circulated an amendment to the Kyoto Protocol in Doha, Qatar. ${ }^{94}$ Known as the Doha Amendment, it includes new commitments for Parties to the Kyoto Protocol to strengthen their resolve and set out a timetable to adopt a universal climate agreement by 2015, which will come into effect in 2020. ${ }^{95}$ It further emphasized the need to increase the ambition to cut greenhouse gases and to help vulnerable countries to adapt.

A shortcoming of the Amendment to the Kyoto Protocol is that so far only 23 countries have ratified it. ${ }^{96}$ Even though the UN is urging for speedy ratification, the process has been slow. Additionally, one of the largest greenhouse gas emitters, the United States, has never ratified the Kyoto Protocol and instead chooses to reduce greenhouse gas emissions under its domestic law on a very limited basis at the national level, with some states regulating more ambitiously than others. ${ }^{97}$ In 2011, Canada

91 Kyoto Protocol to the United Nations Framework Convention on Climate Change, 10 December 1997, 2303 UNTS 148 [Kyoto Protocol].

92 "Making those first steps count: An Introduction to the Kyoto Protocol" UN Framework Convention on Climate Change <http://unfccc.int/essential_ background/kyoto_protocol/items/6034.php> accessed 7 March 2015.

93 ibid.

94 "Status of the Doha Amendment" UN Framework Convention on Climate Change available at <http://unfccc.int/kyoto_protocol/doha_amendment/items/ 7362.php> accessed 7 March 2015.

95 “The Doha Climate Gateway" UN Framework Convention on Climate Change available at <http://unfccc.int/key_steps/doha_climate_gateway/items/7389.php> accessed 7 March 2015.

96 "Status of Doha" (n 94).

97 "Kyoto Protocol and the United States" The Encyclopaedia of the Earth (updated 26 February 2013, 1:10 PM) <www.eoearth.org/view/article/154065/> accessed 17 March 2015. 
withdrew from the Protocol. ${ }^{98}$ Without proper ratification, the Kyoto Protocol is nothing but an empty document that provides no relief to small-island developing nations like the Maldives, who emit very limited amounts of greenhouse gases and aspire to be carbon neutral. Therefore, as it now stands, the Kyoto Protocol has a bleak future and affords no assistance to small-island developing states.

\subsubsection{Paris Convention 2015}

In December 2015, a summit will be held in Paris where 196 countries will meet to sign a new climate change agreement. ${ }^{99}$ The small island states are not willing to accept a weak climate change deal, especially when many of them are facing total annihilation. ${ }^{100}$ The Maldives climate ambassador wants a commitment to a 1.5 degrees Celsius warming goal. ${ }^{101}$ On 13 February, 2015, nations concluded the Geneva Climate Change Talks and were successful in preparing the negotiating text for the 2015 agreement, which contains the views and concerns of all countries. ${ }^{102}$

The negotiating text of the Paris Convention is emphatic. It says, "the objective of this agreement is to achieve net zero greenhouse gas emissions in line with the ultimate objective of the Convention and to maintain and increase resilience to the adverse effects of climate change.”103 The text of the Convention focuses heavily on funding and, similar to the Kyoto Protocol, it also places a burden on developed countries to

98 "Kyoto Protocol" UN Framework Convention on Climate Change available at <http://unfccc.int/kyoto_protocol/items/3145.php> accessed 7 March 2015.

99 Rebecca Willis, "Paris 2015 Getting a Global Agreement on Climate Change" (August 2014) available at <www.christianaid.org.uk/images/paris-2015getting-a-global-agreement-on-climate-change.pdf.>

100 Ed King, "Small islands will not accept weak Paris climate deal" Responding to Climate Change, 12 February 2015 1:59 PM available at <www.rtcc.org/2015/ $02 / 12$ smallislandswillnotacceptweakparisclimatedealofficial/\#sthash. MOcpzbQk.dpuf> accessed 17 March 2015.

101 ibid.

102 Press Release, UN Climate Change Newsroom, Governments Agree the Negotiating Text for the Paris Climate Agreement (13 February 2015) available at <http://newsroom.unfccc.int/unfccc-newsroom/governments-agree-thenegotiating-text-for-the-paris-climate-agreement/> accessed 17 March 2015.

103 Negotiating text of Paris Convention. See "Ad hoc Working Grp. on the Durban Platform for Enhanced Action" Work of the Contact Group on Item Preamble (United Nations Framework Convention on Climate Change, Negotiating text 12 February 2015) <https://unfccc.int/files/bodies/awg/application/pdf/ negotiating_text_12022015@2200.pdf> accessed 17 March, 2015. 
take the lead to mitigate and provide financial assistance. Further, the Convention would place an obligation on developed nations to "provide means of implementation to support ambitious adaptation action." ${ }^{104} \mathrm{It}$ also wants those countries that are in a position to do so to "commit to provide at least USD 50 billion per year during the period from 2020 to 2025 and at least USD 100 billion per year by 2020 for the adaptation activities of developing countries.”105

Along with mitigation and adaptation actions, the focal point of the text is to lower greenhouse gas emissions. It wants "parties to urgently work towards the deep reduction in global greenhouse gas emissions required to hold the increase in global average temperature below $2^{\circ} \mathrm{C} /$ $1.5^{\circ} \mathrm{C}$ above pre-industrial levels and to attain a global peaking of global greenhouse gas emissions as soon as possible." 106 Therefore, the Convention is crucial because there is a need for a climate agreement that would enable the international community to limit global warming to below $2^{\circ} \mathrm{C} .{ }^{107}$

\section{PROPOSAL FOR A SOLUTION}

\subsection{Retaining Sovereignty}

\subsection{The Montevideo Convention Should Permit the Maldives to Remain a State}

Per Jane McAdam, "whether or not a state exists is a mixed question of law and fact." ${ }^{108}$ However, the Montevideo Convention defines a state as one that has (1) a population; (2) a defined territory; (3) a government; and (4) capacity to enter into relations with other states. ${ }^{109}$ Though all four elements need to be present in order for a state to come into existence, the absence of one or all four for that matter, may not necessarily mean

104 ibid para. 51.4.

105 ibid.

106 ibid para. 5.1.

1072015 Paris Climate Conference (COP21), France Diplomatie (2015), <http:// www.diplomatie.gouv.fr/en/french-foreign-policy-1/climate-7436/2015-parisclimate-conference/> accessed 17 February 2015.

108 Jane McAdam, "Disappearing States", Statelessness and the Boundaries of International Law' in Jane McAdam (ed.) Climate Change and Displacement Multidisciplinary Perspectives (Oxford: Hart Publishing, 2010) 105, 110.

109 Montevideo Convention on the Rights and Duties of States (n 79). 
the end of a state. ${ }^{110}$ The Holy See is one such example of such a state. It serves as "the supreme organ of government of the Catholic Church," yet it lacks the traditional population of its own. ${ }^{111}$ Irrespective of a set population, the Holy See is recognized as a sovereign state by the UN and is entitled to the same privileges as other states. ${ }^{112}$

Somalia is another such example as it has on numerous occasions operated out of and carried out governmental functions from its neighbouring country due to unrest within its own territory. ${ }^{113}$ There is no requirement under the Montevideo Convention for state governments to be located within its own territory; therefore, governments can function from a state that is not their own, a concept known as government in exile. ${ }^{114}$ If the Maldives opts to relocate to another state, its government would be considered a government in exile that, despite being away from its homeland, can still continue to operate. If a government were still carrying out functions, it would enable it to enter into relations with other nations. Additionally, the government of the Maldives plans to purchase land in another state and move the entire nation. Therefore, it would also meet the population and the territory elements of the Montevideo and would still be able to retain its sovereignty.

Another concept gaining significance in the climate change sector is the idea of "The Nation Ex-Situ."115 An alternative form of statehood proposed by Professor Maxine Burkett, "the government of ex-situ nations would sit in a permanent location and manage the affairs of the state at a distance." ${ }^{116}$ Per the author:

110 McAdam (n 108)

111 The Holy See at the UN: A State or a Religion? Church and state <http:// churchandstate.org.uk/2012/08/the-holy-see-at-the-un/> accessed 20 March 2015.

112 ibid.

113 "Climate Change and the Jurisprudence of Statehood: Is a State Without a Territory Still a State?” View from LL2, (Jan. 12, 2010) < http://viewfromll2.com/ 2010/01/12/climate-change-and-the-jurisprudence-of-statehood-is-a-statewithout-a-territory-still-a-state/> accessed 20 March 2015.

114 McAdam (n 108) 116.

115 Maxine Burkett, 'The Nation Ex-Situ: On climate change, de-territorialized nationhood and the post-climate era' in Michael B. Gerrard \& Gregory E. Wannier (eds.) Threatened Island Nations: Legal Implications of Rising Seas and a Changing Climate (2013) 89 available at <www.law.hawaii.edu/sites/ www.law.hawaii.edu/files/content/coliver/345-374\%20Burkett.pdf $>$ accessed 20 March 2015.

116 ibid 107. 
The role of the government ex-situ would have a similar mandate, greater emphasis would be placed on preserving all elements of the nation-state that should endure extraterritorially - key among them are the persistence of culture, connection amongst its people, and the security and well-being of its citizens. The citizens of the ex-situ nation will almost certainly be scattered across the globe; and, the government of the Nation Ex-Situ can serve as a vital political and cultural nucleus. ${ }^{117}$

Burkett based her proposal on the UN International Trusteeship System, in which political trustees are appointed to hold in trust and oversee territories for the benefit of the occupants of those territories. ${ }^{118}$ In cases such as the Maldives who will lose all territory, Burkett recommends that a trustee should serve as a temporary "body that governs alongside the existing in-situ government of the endangered state, to facilitate an orderly transition for the peoples and governance mechanisms of that state." 119 Once the population has significantly relocated, the temporary body would merge with the relocated government.

Professor Burkett is aware that population of a submerged state that relocates would eventually become scattered and moved across the globe, which is why she believes the Nation Ex-Situ would be essential and beneficial. If the Maldives relocated, the new area to which they would relocate would serve as a pivotal point where a government could still function. Even if the population scatters, the government could serve as the centre for those dispersed individuals to call home. The Nation Ex-Situ proposal is new and still in need of international recognition and acceptance. ${ }^{120}$ The idea should be accepted because it would be a great benefit to endangered states like the Maldives, which could still advocate and protect their citizens when their homes become extinct.

\subsubsection{Responsibilities of the Home State and Host State}

Pursuant to the Refugee Convention, all responsibilities are placed on the host state. The Convention requires that refugees receive human rights protections equal to aliens or nationals in the host states. ${ }^{121}$ The host state

117 ibid.

118 ibid 108.

119 ibid 110.

120 ibid 113.

121 Convention Relating to the Status of Refugees (n 58) arts. 3-30. 
is also required to provide humanitarian aid, as well as allow refugees to exercise their basic rights. ${ }^{122}$ With respect to the duties of refugees, under the Convention "every refugee has duties to the country in which he finds himself, which require in particular that he conform to its laws and regulations as well as to measures taken for the maintenance of public order." 123 However, the permeation of a vast number of people into a state due to climate changes places an undue burden on a host state that allows them to come in.

States that host refugees encounter large financial costs in terms of providing adequate housing and jobs. ${ }^{124}$ Additionally, hosting such a large number of refugees places a considerable amount of economic, environmental, and infrastructural costs on the host state. ${ }^{125}$ The influx of such a number of refugees can also decrease local wages and put a substantial strain on the infrastructure and the availability of land. ${ }^{126}$

The Committee on Economic, Social, and Cultural Rights (CESCR), argues that "states have a joint and individual responsibility" to provide financial assistance to those states hosting refugees. ${ }^{127}$ However, at the international level, even though States should provide funding to those states that host refugees, such funding is not an obligation. Therefore, there should be a global fund, which should place an obligation on all states to provide financial assistance to host states to ease their burden of hosting refugees. The precedent of a global fund has already been set by the UNFCCC, which has a fund to implement international cooperation and assistance. ${ }^{128}$ The states at the 2015 convention can look to the UNFCCC fund and agree on a funding scheme that will be beneficial for host states.

As home states do not have control over their nationals once they become refugees, the host state should provide for the refugees as its own. The home state should not, however, be left to silently reap the benefits. Therefore, if the Maldives chooses the option to relocate, as a

122 ibid.

123 ibid art. 2.

124 "The Role of Host Countries: The Cost and Impact of Hosting Refugees" Executive Committee of the High Commissioner's Programme (31 May 2011) 2 <www.refworld.org/pdfid/520b3fa24.pdf> accessed 20 March 2015.

125 ibid.

126 ibid.

127 Bonnie Dochertya \& Tyler Giannini (n 60) 383.

128 ibid 385. 
home state of climate change refugees, it should share the responsibilities and work together with the host state to the extent possible. As there is no separate document affording rights to climate change refugees, host states should afford the same human rights protections to climate change refugees as are given to refugees under the Refugee Convention. However, home states should provide financial and material assistance where possible. ${ }^{129}$ Home states should also help with remedial measures to the extent possible and should cooperate in addressing refugee problems. ${ }^{130}$ By having the host and home states share responsibilities, the parties can work together as a team to benefit the people and lessen the burden that is placed solely on the host state.

\subsection{Artificial Island}

The United Nations Convention on the Law of the Sea (UNCLOS) ${ }^{131}$ does not have a definition of an artificial island. Legal scholars have defined artificial islands as "constructions created by man's dumping of natural substances like sand, rocks and gravel on the seabed." 132 UNCLOS Article 121(1) defines an island as "a naturally formed area of land, surrounded by water, which is above water at high tide." ${ }^{133}$ UNCLOS also addresses the legal status of artificial islands. Article 60 is dedicated to artificial islands and other structures in the exclusive economic zone (EEZ). It provides that "artificial islands, installations and structures do not possess the status of islands." ${ }^{134}$ UNCLOS further states that "Rocks which cannot sustain human habitation or economic life of their own shall have no exclusive economic zone or continental shelf." ${ }^{135}$ Therefore, pursuant to UNCLOS, an island cannot claim an EEZ or a continental shelf if it is so submerged that it can no longer support human life. ${ }^{136}$

129 ibid 380.

130 ibid 381 .

131 United Nations Convention on the Law of the Sea [UNCLOS], 10 December 1982, 1833 UNTS 397.

132 Grigoris Tsaltas, “Artificial Islands and Structures as a Means of Safeguarding State Sovereignty Against Sea Level Rise. A Law of the Sea Perspective” 7 (2010), <http://www.iho.int/mtg_docs/com_wg/ABLOS/ABLOS_Conf6/S2P3P.pdf $>$ accessed 20 March 2015.

133 UNCLOS (n 131) art. 121(1).

134 ibid art. 60(8).

135 ibid art. 121(3).

136 Gagain (n 45) 98. 
Artificial islands have been around for some time now and have been used by countries such as Dubai as a tourist spot housing luxurious resorts. ${ }^{137}$ Per UNCLOS Article 60: "The coastal State shall have exclusive jurisdiction over such artificial islands, installations and structures, including jurisdiction with regard to customs, fiscal, health, safety and immigration laws and regulations." 138 However, these rights are not unlimited. UNCLOS lays out several limitations such as notice must be given of the construction, they need to establish safety zones to ensure safety of navigation, and artificial islands cannot be established where there are recognized sea-lanes because they are essential for international navigation. ${ }^{139}$ Most importantly, because artificial islands are not recognized as islands, "they have no territorial sea of their own, and their presence does not affect the delimitation of the territorial sea, the exclusive economic zone or the continental shelf." 140

The Maldives is already experienced with artificial islands as the commencement of its own artificial island began in 1997 and it anticipates development of all phases by $2020 .{ }^{141}$ Hulhumale is essentially a younger sister to the island of Male and was built as a solution to Male's growing population. ${ }^{142}$ Once fully developed, Hulhumale should be able to accommodate about 100,000 people, which is equivalent to the current population of Male. ${ }^{143}$ Additionally, Hulhumale is erected within the territorial waters of the Maldives; ${ }^{144}$ however, as it cannot sustain the full population of the Maldives, additional artificial islands will have to be built. Furthermore, whether Hulhumale can maintain maritime zones and satisfy the elements of statehood once the Maldives become submerged is a question of concern here. ${ }^{145}$

As no island state has been considered completely submerged, as of now, the law and discussion on the matter of artificial islands is relatively

137 Fabrizio Bozzato, “Dryland: Artificial Islands as New Oceanscapes” Tamkang University (Taiwan 2013) 3 available at <www.jfs.tku.edu.tw/wp-content/ uploads/2013/10/174-A01.pdf> accessed 20 March 2015.

138 UNCLOS (n 130) art. 60(2).

139 ibid art. 60(3)-(7).

140 ibid art. 60(8).

141 “Introduction” Housing Development Corporation <http://www.hdc.com.mv/ development/introduction.php> accessed 24 March 2015.

142 "Introducing Hulhumale" Lonely Planet <www.lonelyplanet.com/maldives/ hulhumale> accessed 23 March 2015.

143 ibid.

144 Gagain (n 45) 82.

145 ibid 87. 
new. ${ }^{146}$ Nonetheless, in light of the current sea level rise and the threat it poses to states such as the Maldives, several legal scholars have proposed to expand the text of UNCLOS to consider artificial islands as an acceptable state. ${ }^{147}$ The Maldives would have to advocate for such a change and the disadvantage of their imminent extinction works to their advantage here. However, they would have to be mindful that the construction of another artificial island does not violate UNCLOS and they would need to be attentive when deciding on a location that they do not endanger the marine environment. ${ }^{148}$

For a country such as the Maldives that is facing extinction, an artificial island might be one of its best options. An artificial island would protect the Maldives from being at the mercy of other states for land. It would also allow it to keep its population together and govern it as it did on its original island. Further, if the Maldives were able to move to make an artificial island its home, it would also satisfy the elements of statehood under the Montevideo Convention. So long as the Maldives does not claim additional maritime zones, UNCLOS should permit the expansion of its text to recognize artificial islands as states, and other states should recognize the artificial island as a territory. ${ }^{149}$ In short, an artificial island would be a replica of the original state, which the Maldives would not be able to duplicate if it relocates.

\subsection{Relocation to Australia}

Listed as the sixth largest country in the world in terms of landmass, Australia ${ }^{150}$ is located approximately 6,000 kilometres from the capital of the Maldives. ${ }^{151}$ Owing to Australia's abundance of space, Nasheed's

146 Tsaltas (n 132) 14.

147 Gagain (n 45) 107.

148 ibid 110.

149 Jenny Grote Stoutenberg, "When do States Disappear? Thresholds of Effective Statehood and the Continued Recognition of 'De-territorialized' Island States" in Michael B. Gerrard \& Gregory E. Wannier (eds.) Threatened Island Nations: Legal Implications of Rising Seas and a Changing Climate (2013) 57, 63.

150 Australia is approximately $7,692,024 \mathrm{~km}^{2}$ and is the largest country in the continent of Oceania, see 'Countries of the World by area', Nations Online <www.nationsonline.org/oneworld/countries_by_area.htm> accessed $18 \mathrm{March}$ 2015.

151 Distance between Perth, Australia and Malé, Maldives, Date and Time <http:/ /dateand time.info/distance.php?id1=2063523\&id2 $=1282027>$ accessed 20 March 2015. 
government had listed it on the top of the list as a possible country for relocation. In addition, Nasheed had opened up the sovereign savings account, funds from which he had used to purchase land in Australia. ${ }^{152}$ Australia and the Maldives have shared a warm relationship which remained strong when Nasheed was president. ${ }^{153}$ Australia continues to provide aid to the Maldives in the form of financial assistance as well as offering awards to Maldivian students to study at Australian Universities. ${ }^{154}$ Notwithstanding the ample land space and good relations, Australia has been silent on the issues of allowing climate change refugees to come into its territory. Its neighbour, New Zealand, has already announced that it is not willing to provide a permanent home for climate change refugees. ${ }^{155}$ As at the time of this writing, Australia has not indicated whether it would follow the same path as its neighbour.

\subsubsection{Funding Concerns}

The large infiltration of refugees is expensive not only for the home state, but for the host state as well. Though Australia is a developed country and much more economically stable compared to the Maldives, taking in a large population takes a toll on any country and its economy. Providing adequate housing, jobs, and other benefits requires large sums of money, which would pose a considerable burden on the Australian economy. Additionally, even though the international community should provide funds to those states that take in large numbers of climate change refugees, it is not an absolute obligation.

152 James Burgess, "Maldives Buying Land in Australia as Preparation for Mass Migration” Oil Price (10 January 2012 10:43 PM) <http://oilprice.com/LatestEnergy-News/World-News/Maldives-Buying-Land-In-Australia-AsPreparation-For-Mass-Migration.html> accessed 20 March 2015.

153 Owing to the current unrest in the Maldives, there are no reports that suggest whether the new President of the Maldives shares the same relations with Australia.

154 "Overview of Australia's aid program to the Maldives" Australian Government Department of Foreign Affairs and Trade <http://dfat.gov.au/geo/maldives/ development-assistance/pages/development-assistance-in-maldives.aspx $>$ accessed 28 March 2015.

155 In 2014, New Zealand Court of Appeals refused to grant refugee status to Ioane Teitiota, a citizen of Kiribati, who had been living in New Zealand since 2007 because of Kiribati facing extinction due to sea level rise. See "Climate Change Refugee Claim: Deportation fears for Kiribati man after losing appeal” ABC (12 May 2014) <www.abc.net.au/news/2014-05-12/an-kiribati-man-loses-climatechange-refugee-appeal/5447170> accessed 20 March 2015. 
The international community does not recognize climate change refugees as a protected class under the current legal framework. Consequently, reaching out to other foreign nations for financial assistance can be a daunting task. Therefore, the decision of the 2015 Paris Conference of the Parties is imperative, as it would provide support to countries that allow climate change refugees to come in. A global fund would be of major assistance here to help alleviate the burden placed on the host state.

\subsubsection{Cultural and Political Concerns}

Unlike India, which is another country for relocation considered by Maldives, Australia and Maldives do not share the same cultural values. Christianity is the largest religion in Australia and the physical features of Australians are similar to those of Caucasians. ${ }^{156}$ By contrast, the Maldivians come from a cultural background where the women tend to wear clothes that cover more of their bodies, whereas, in Australia, the women have freedom in their choice of clothes. ${ }^{157}$ Additionally, the languages used and foods the countries consume are also vastly different. While the Australians like to indulge in a fair amount of alcohol, the consumption of liquor is banned in the Maldives. ${ }^{158}$ Furthermore, the political systems of the two countries differ significantly.

Australia is a constitutional monarchy with the prime minister and Queen Elizabeth as the heads of state. ${ }^{159}$ On the contrary, the Maldives government is a Republic whose law is predominately based on Islamic law with some aspects of English common law. ${ }^{160}$ The fact that Queen Elizabeth is a head of state in Australia might be a cause of concern as the Maldives achieved its independence from United Kingdom. Additionally, even though the Maldives has voiced its interest in moving to Australia,

156 "Religion in Australia" UNSW International <http://www.international.unsw. edu.au/living-sydney/religion/> accessed 24 March 2015.

157 “Cultural Practices” Weebly <http://maldives-exchange-program.weebly.com/ cultural-practices.html> accessed 24 March 2015.

158 Resorts and Hotels located outside the capital city offer liquor for patrons. See Frequently Asked Questions: Maldives, Vermillon Maldives <www.vermillion maldives.com/faq.htm\#travel7> accessed 10 April 2015.

159 “Our Government" Australian Government < www.australia.gov.au/aboutaustralia/our-government> accessed 24 March 2015.

160 "Government" The Maldives < www.themaldives.com/government/> accessed 24 March 2015. 
the Australian government has not expressed any interest in the matter.

Irrespective of the above issues and concerns, if the Maldives were to seriously consider relocation to another country, Australia would be the best option. The wealth of land that Australia has to offer cannot be overlooked because it allows Australia the liberty to take in such a large population without being overly concerned by a drain on available land and other resources. While it is true that Australia and the Maldives differ substantially in terms of cultural and religious values, this could also be an advantage. Unlike India, as discussed below, which has a large Muslim population and a history of Hindu-Muslim clashes, Australia has no such issues. If Australia is able to provide the Maldives with separate area of land, the possibilities of Australians and the Maldivians living in harmony are higher than those of India. For all of these reasons, Australia is the best choice as a relocation destination for the Maldives.

\subsection{Relocation to India}

With a distance of only 340 kilometres between them, India is one of the closest countries to the Maldives. ${ }^{161}$ Another country considered for a possible relocation, India shares several similarities with the Maldives. For instance, the population of the Maldives is predominately Muslim, while India is third on the list of countries with the most Muslims in the world. ${ }^{162}$ Further, the Maldivians and Indians share similar features in terms of looks including the brownish skin tone and hair texture, as many Maldivians trace their descent back to India. ${ }^{163}$ The Maldivian cuisine, traditional attire, and many traditions, such as removing one's shoes when entering a home, are also influenced from India. The Maldives also has a large population of Indians, including doctors, nurses, teachers, and technicians who reside on the island. ${ }^{164}$ Therefore, the Maldives is significantly similar to India in terms of their culture and traditions.

Additionally, India and the Maldives also enjoy positive relations politically and economically. India was the first country to recognize the Maldives as a State after its independence in 1965 and was also one of the

161 “Why Visit Maldives?” Maldives Embassy < www.maldivesembassy.cn/visitmaldives/why-visit-maldives/> accessed 9 March 2015.

162 “Mapping Global Muslim Population” Pew Forum <www.pewforum.org/2009/ 10/07/mapping-the-global-muslim-population/> accessed 9 March 2015.

163 ibid.

164 “India-Maldives Relations” MEA (Jan. 2012) <http://mea.gov.in/Portal/ ForeignRelation/Maldives-January-2012.pdf $>$ accessed 9 March 2015. 
first to establish diplomatic relations with the country. ${ }^{165}$ India was also one of the first countries to rush to the aid of the Maldives when the tsunami hit in 2004. ${ }^{166}$ Along with providing financial assistance to the Maldives in the face of crisis, India is one of the largest importers of products from the Maldives. ${ }^{167}$ India has also provided the Maldives with military assistance when mercenaries, largely drawn from a Sri Lankan Tamil insurgent group, had gained access to the Maldivian capital and were able to take control of key points in the city. ${ }^{168}$

India and the Maldives share warm relations and cultural ties, which makes India a viable relocation choice for the Maldives However, there are several disadvantages such as the ones discussed below that also come with such a large move.

\subsubsection{Funding Concerns}

As discussed above, hosting refugees can be expensive for host states. A major concern for the Maldives moving to India is that, unlike Australia, India is a developing country and currently has its own concerns of being able to offer adequate jobs to its own citizens. The population of India is also a major setback. Currently listed as the second most populated country in the world with a population of over 1.2 billion, ${ }^{169}$ India is already extremely crowded and considered a third-world country, a label that it is working to leave behind. Therefore, there is a concern as to whether India would be able to sustain and adequately provide for the 300,000 plus Maldivians that will expect adequate housing and jobs.

\subsubsection{Cultural and Political Concerns}

Although India and the Maldives share a vast number of similarities in terms of culture and good political relations, there are several concerns that might pose a problem for the Maldives. The Muslims in India amount

165 “India \& Maldives" IASSCORE. <www.iasscore.in/international-details12.html> accessed 10 March 2015.

166 ibid.

167 "Mapping Global Muslim Population” (n 162).

168 David Brewster, “Operation Cactus: India's 1988 intervention in the Maldives” Pragati the Indian National Interest Review (April 18, 2014) <http:// pragati.nationalinterest.in/2014/04/operation-cactus-indias-1988-interventionin-the-maldives/>, accessed 10 March 2015.

169 “The World Factbook: India” $C_{I} A$, <www.cia.gov/library/publications/theworld-factbook/geos/in.html> accessed 6 March 2015. 
to only about 13.4 per cent of the population ${ }^{170}$ making them a minority in the country. Additionally, the Hindus and Muslims of India have had several religious clashes in the past and still do not live in absolute harmony. A large infiltration of Muslims who do not speak the same language and are not familiar with Hinduism might lead to added unrest. There is also no guarantee that even the Muslims of India would welcome the Muslims of the Maldives wholeheartedly. Though their religion might be same, the Indian Muslims might consider themselves superior and might view the Maldivian Muslims as a potential threat.

Political clashes could be another threat the Maldives would have to consider when considering a move to India. The Maldives government is a Republic whose law is based on Islamic law with mixtures of English common law. ${ }^{171}$ India, on the contrary, is a Federal Republic whose law is based on the Hindu law, English common law, and Islamic law in some areas. ${ }^{172}$ Whereas the President is the highest authority in the Maldives, the majority of the power in India is vested in the Prime Minister. Unfortunately, India is not one such country that would permit foreigners to have easy access in its political system and is also viewed by its counterparts to be a corrupt country in regards to politics. Therefore, there is a strong possibility that the Maldivians would not be afforded the rights they deserve if they relocate to India.

\section{CONCLUSION}

The Maldives is not the only small island nation that is on the brink of extinction. Other nations such as Kiribati, Tuvalu, and the Marshall Islands are facing a similar fate due to sea level rise. Despite the fact that so many nations will become completely submerged and millions will become homeless, the international community has been of little assistance. In fact, some of the countries that are the major contributors of gas emissions and possibly a significant cause of the Maldives current situation, have chosen to take a step back and have not ratified the climate change treaties available to date.

The United Nations should expand the scope of UNCLOS to cover artificial islands as islands that can have maritime zones because

170 ibid.

171 Our Government (n 159).

172 “Indian Law" Encyclopaedia Britannica <http://www.britannica.com/ EBchecked/topic/285760/Indian-law> accessed 1 April 2015. 
submerging nations due to sea level rise is a sad but true reality. By allowing artificial island to be an acceptable territory would also save the Maldives money as they can invest in the island instead of squandering funds to buy new land in other countries. The Maldives would also not have to consider moving to a foreign land and its people would not have to worry about cultural and political clashes because it can continue reside on its own separate artificial island.

As the UN Convention of Refugees makes no mention of climate change refugees, the international community should step in and provide assistance and support to the Maldives. If an artificial island is not a feasible option, Australia, which has a wealth of land, should break its silence and welcome the Maldives to purchase land within its territory. Regardless of the fact that the Maldivians would be residing in another country, the Montevideo Convention should still permit the Maldives to retain its sovereignty. Retaining its sovereignty while operating out of another nation would be very beneficial for Maldives as it would allow the Maldivians to keep their culture and politics intact.

Although this article only references the plight of the Maldives, the solutions proposed in this article would be applicable to other small island nation-states that are facing the same unfortunate outcome. In fact, nations such as Kiribati and Tuvalu have also considered the above proposals as possible remedies for their situations. Therefore, these proposals would be beneficial to many island nations, similar to the Maldives, that are also on the threshold of becoming submerged. 